\title{
CARVACROL REDUCES THE SEVERITY OF INTESTINAL MUCOSAL DAMAGE CAUSED BY INTESTINAL ISCHEMIA - REPERFUSION IN RATS
}

\author{
HULYA OZTURK, AYHAN CETINKAYA, SELMA ERDOGAN DUZCU, OZGUR MEHMET \\ YIS, HAYRETTIN OZTURK*
}

Abant Izzet Baysal University, Medical School, Bolu, Turkey

*corresponding author: hayrettin.ozturk@ibu.edu.tr

\begin{abstract}
Intestinal ischemia-reperfusion (I/R) is a pathophysiological process that is common in many clinical conditions such as shock, sepsis, mesenteric thrombosis, necrotizing enterocolitis, and bowel transplantation. Our aim in this study was to investigate the potential protective effects of carvacrol on the intestinal $I / R$ injury in a rat model. The 30 rats were randomly divided into three groups $(\mathrm{n}=10)$ : The sham-control (group 1$)$ underwent only the separation of the superior mesenteric artery but not the occlusion. In the I/R-untreated (group 2) and I/R-carvacrol-treated groups (group 3), the superior mesenteric artery was clamped for $45 \mathrm{~min}$, followed by $60 \mathrm{~min}$ of reperfusion. 2 hours before ischemia, the group 3 of rats received an intraperitoneal injection of carvacrol at a dose of $75 \mathrm{mg} / \mathrm{kg}$ bw. At the end of the experiment, intestinal tissue samples were taken for oxidative stress assessment including superoxide dismutase (SOD), malondialdehyde (MDA), myeloperoxidase (MPO), total antioxidant status (TAS) and total oxidant status (TOS). In addition, the intestine sections were stained with haematoxylin-eosin to evaluate morphological changes and immunohistochemical staining was performed for inducible nitric oxide synthase (iNOS) and endothelial nitric oxide synthase (eNOS) assessment. The intestinal mucosa was significantly damaged in the group 2 , which was markedly attenuated after carvacrol treatment. The tissue MDA, MPO and TOS content increased significantly in the group 2, but they were reduced by carvacrol treatment. In addition, SOD and TAS activity increased markedly in group 3 as compared to group 2. Immunohistochemical staining showed that iNOS increased and eNOS decreased in group 2, which was improved in reverse direction after carvacrol treatment. Carvacrol may be a potential therapeutic agent for the treatment of intestinal I/R injury.
\end{abstract}

\section{Rezumat}

Procesul de ischemie-reperfuzie intestinală (I/R) este frecvent întâlnit în multe afecțiuni clinice, cum ar fi septicemia, tromboza mezenterică, enterocolita necrozantă și transplantul de intestin. Scopul acestui studiu a fost de a investiga potențialul efect protector al carvacrolului asupra leziunilor $\mathrm{I} / \mathrm{R}$ intestinale într-un model experimental pe şobolan. Cei 30 de şobolani au fost randomizați în trei grupuri $(\mathrm{n}=10)$ : control (grupul 1) - a suferit doar separarea arterei mezenterice superioare, dar nu și ocluzie; grupul 2 - cu I/R şi grupul 3 - I/R-carvacrol, la care artera mezenterică superioară a fost obstrucționată timp de $45 \mathrm{~min}$, urmând 60 min de reperfuzie. Cu 2 ore înainte de ischemie, șobolanii din grupul 3 au primit $75 \mathrm{mg} / \mathrm{kgc}$ carvacrol, i.p.. La sfârșitul experimentului, s-au prelevat probe de țesut intestinal pentru evaluarea stresului oxidativ. Sa-u determinat: activitatea superoxid dismutazei (SOD) și mieloperoxidazei (MPO), malondialdehida (MDA), statusul antioxidant total (TAS) și statusul oxidativ total (TOS). În plus, secțiunile intestinale au fost evaluate privind modificările morfologice existente, iar studiile imunohistochimice au evidenţiat expresia nitric oxid sintazei inductibile (iNOS) şi endoteliale (eNOS). Mucoasa intestinală a fost afectată în grupul 2, proces atenuat în mod semnificativ după tratamentul cu carvacrol. Conținutul tisular de MDA, MPO și TOS a crescut semnificativ în grupul 2, dar nivelele acestora au fost reduse prin tratamentul cu carvacrol. În plus, activitățile SOD și TAS au crescut semnificativ în grupul 3, comparativ cu grupul 2. Colorarea imunohistochimică a demonstrat că iNOS a crescut și eNOS a scăzut în grupul 2. Carvacrolul poate fi un potențial agent terapeutic pentru tratamentul leziunilor I/R intestinale.

Keywords: carvacrol, ischemia-reperfusion injury, oxidative stress, intestine, rat

\section{Introduction}

Ischemia-reperfusion (I/R) of the intestine is a pathological process that occurs in many diseases and surgical situations such as major vascular surgery, shock, intestinal and liver transplantation, severe acute pancreatitis, volvulus, and necrotizing enterocolitis $[1,2]$. During $\mathrm{I} / \mathrm{R}$, the release of cytokines and translocation of intestinal microflora and endotoxins together with an increased permeability in the mucosa are known causes of tissue damage. Clinically, this pathological process has high morbidity and mortality, resulting in sepsis, systemic inflammatory response syndrome, as well as multiple organ failure and subsequent fatal deaths in critically ill cases $[3,4]$. Although the factors that play a crucial role in the development of intestinal mucosal damage have been extensively studied, this issue remains of high 
importance. However, it is claimed that certain mediators such as polymorphonuclear neutrophils, increased adhesion molecules, reactive oxygen species (ROS), nitric oxide (NO) and some cytokine/chemokine release are involved [5-8]. Additionally, previous animal studies have shown that ROS is the end result of oxygen imbalance, which leads to the accumulation of reactive aldehydes by lipid peroxidation in mitochondria [8]. Then, it has been suggested that ROS production occurring during the reperfusion period plays a key role for uncontrolled oxidative stress, and increased ROS may also induce the inflammatory cascade [9]. Carvacrol, a monoterpenic phenol of Lamiaceae family, has been widely used in food industry for a long time [10]. Several studies suggest that carvacrol has antioxidant, anti-inflammatory, cytoprotective, antitumor and antimicrobial properties [11-13]. Also, carvacrol, a potent antioxidant, can be effective in the treatment of many illnesses.

There are no studies assessing carvacrol's ability to reduce intestinal damage in mesenteric $I / R$ to the extent that we search the literature. Moreover, the role of carvacrol in reducing lipid peroxidation and its successful experiments in other organs with therapeutic applications such as anti-inflammatory, cytoprotective and antimicrobial, it seems appropriate to hypothesize that carvacrol may have a therapeutic effect in intestinal I/R. Therefore, the main purpose of this study was to investigate the role of carvacrol on oxidative stress in intestinal $I / R$ injury in a rat model and to evaluate the potential mechanisms underlying the protective effects of carvacrol.

\section{Materials and Methods}

\section{Animals}

Sprague Dawley rats, (8 - 10-year-old male, 250 - 280 g), were used in this study, and All the procedures in this study were approved by the Institutional Animal Care and Use Committee of Abant Izzet Baysal University (Bolu, Turkey) (Number/ID (s):2017/34), and animals were handled according to the Guide for the Care and Use of Laboratory Animals (1996). The rats were individually housed under a 12/12 h light/ dark cycle, with free access to tap water and food. Room temperature and humidity were kept at $22 \pm 2{ }^{\circ} \mathrm{C}$ and $55 \pm 5 \%$, respectively.

\section{Mesenteric ischemia-reperfusion injury}

$\mathrm{I} / \mathrm{R}$ injury model was performed as previously described [14]. The rats were anesthetized by xylazine $(10 \mathrm{mg} / \mathrm{kg}$ bw, Rompun ${ }^{\circledR}$; Bayer AG, Leverkusen, Germany) and ketamine hydrochloride $(100 \mathrm{mg} / \mathrm{kg}$ bw, Ketalar, Eczacıbasi, Turkey). The rats were placed in supine position and secured in a dissection tray. The abdominal region was shaved and cleaned with anti-septic solutions. It was entered into the abdomen through a midline laparotomy. The superior mesenteric artery was gently dissected and occluded with a microvascular clamp, then, intestinal ischemia was maintained for $45 \mathrm{~min}$. The abdomen was temporarily covered with a sterile plastic wrap to minimize evaporative loss. Following ischemia, the clamp was removed and a 60 -min reperfusion was applied. In the sham operation group, the superior mesenteric artery was isolated, but it was not occluded.

30 rats were randomly divided into three groups, namely, the sham-control group (group 1), I/R-untreated group (group 2), and I/R-carvacrol treated group (group 3), with 10 animals in each group. The sham-control group underwent only the separation of the superior mesenteric artery but not the occlusion. In the I/Runtreated and I/R-carvacrol treated groups, the superior mesenteric artery was clamped for $45 \mathrm{~min}$, followed by $60 \mathrm{~min}$ of reperfusion. At 2 before ischemia, the I/R-carvacrol treated group rats received an i.p. injection of carvacrol at a dose of $75 \mathrm{mg} / \mathrm{kg}$ bw (Sigma-Aldrich, St. Louis, MO, USA). Sham-control and I/R-untreated groups received vehicle (25\% dimethyl sulfoxide (DMSO) in normal saline) $10 \mathrm{~mL} / \mathrm{kg}$ bw according to the same protocol.

At the end of experiments, intestine tissue samples were collected, $(10 \mathrm{~cm}$ away from the ileocecal junction of the isolated segment of the intestine) and, flushed with saline. Then, the samples were divided into two parts, one part of the tissue samples were frozen immediately using liquid nitrogen for analysis of biochemical and immunohistochemical studies, and stored at $-80^{\circ} \mathrm{C}$ until analysis. The remaining part of intestine samples were placed in a solution of $10 \%$ formaldehyde for histopathological studies.

\section{Histopathologic Examination}

Terminal ileum segments were embedded in paraffin, and $5 \mu \mathrm{m}$ thick sections were stained with haematoxylin and eosin (H\&E). The degree of intestinal tissue injury was evaluated under a light microscope (TE300; Nikon, Tokyo, Japan) by a blinded pathologist. Chiu scale [15] consists of 5 grades (G0 - G5) and it was used to assess the histological damage of the intestine as follows: grade 0 - mucosa without changes; grade 1 subepithelial space at the tips of the villi; grade 2 extension of the subepithelial space; grade 3 - massive desquamation from the tips of the villi; grade $4-$ entirely desquamated mucosa with markedly capillary congestion; and grade 5 - derangement of lamina propria with ulceration.

Determination of tissue malondialdehyde, superoxide dismutase and myeloperoxidase

In a similar manner to the previously described method [16], the samples were thawed before study. Each tissue was homogenized once in $1 \mathrm{~mL}$ phosphatebuffered saline. Samples were frozen and thawed twice to facilitate cell membrane disintegration. The homogenate was centrifuged at $4{ }^{\circ} \mathrm{C}$ at $5,000 \mathrm{~g}$ for 5 $\mathrm{min}$, and the supernatant was removed. Malondialdehyde (MDA) concentrations were measured using commercially available colorimetric assay kits according 
to manufacturer instructions (Cayman Chemical Co., Ann Arbor, USA). Superoxide dismutase (SOD), and Myeloperoxidase (MPO) activities were measured using commercially available enzyme-linked immunosorbent assay kits according to manufacturer instructions (Cusabio Biotech, Wuhan, PRC). BCA protein assay was used for the quantitation of tissue total protein (Thermo Fisher Scientific Inc., Rockford, USA).

Measurement of tissue TAS and TOS levels

The total antioxidant status (TAS) and total oxidant status (TOS) levels in the intestinal tissue were measured using a Beckman Coulter AU680 analyser (Beckman Coulter) with commercial reagents (Rel Assay Diagnostic, Gaziantep, Turkey).

Immunohistochemical examinations

All the intestinal tissue specimens were embedded in paraffin blocks and stored at $4{ }^{\circ} \mathrm{C}$. The specimens were later deparaffinized, rehydrated, and sectioned at $5 \mu \mathrm{m}$. The sections were microwave pre-treated in $10 \mathrm{mM}$ citrate buffer for $20 \mathrm{~min}$, followed by cooling at room temperature for $20 \mathrm{~min}$ and washing with buffer solution for $10 \mathrm{~min}$. The expression of endothelial nitric oxide synthase (eNOS) and inducible nitric oxide synthase (iNOS) was evaluated using eNOS polyclonal rabbit antibody (Thermofisher Scientific, PA516887) and iNOS polyclonal rabbit antibody (Thermo Fisher Scientific, PA5-16855), respectively. In each group, the expression of eNOS and iNOS were scored semi-quantitatively as follows: no staining (score 0 ), mild staining (score 1), moderate staining (score 2) and severe staining (score 3 ).

Statistical analysis

Data were analysed using SPSS Statistics software Version 23 (IBM Corporation, Armonk, NY, USA). All data sets were first assessed for normality with the Kolmogorov-Smirnov test and Shapiro-Wilk test. Data

are expressed as means \pm standard deviation. If the data were normally distributed, the comparison of multiple groups was performed using the one-way analysis of variance (ANOVA) followed by Tukey post hoc analysis to compare differences between individual groups (SOD, MDA, MPO, TAS, and TOS 's tissue levels); if the data were not conforming to the normal distribution, then the comparison of multiple groups was carried out by Kruskal-Wallis test (intestinal mucosal injury score, iNOS, and eNOS), and differences between individual groups were compared by MannWhitney $U$ test. A p value of $<0.05$ was considered to indicate statistical significance.

\section{Results and Discussion}

As shown in Table I, the tissue MDA levels were significantly increased in the I/R-untreated group as compared to the sham-control $(\mathrm{p}<0.001)$. Moreover, in the I/R-untreated group, the SOD activity was reduced in the presence of $\mathrm{I} / \mathrm{R}$ compared with the sham-control group $(p<0.02)$. However, in the I/Rcarvacrol treated group rats, the MDA contents reduced significantly and the SOD activity increased markedly compared with the I/R-untreated group ( $\mathrm{p}<$ 0.004 and $p<0.001$, respectively). As compared to the sham-control group, MPO activity increased significantly in the I/R-untreated group $(p<0.001)$. However, tissue MPO activity decreased significantly after carvacrol treatment $(\mathrm{p}<0.001)$ (Table I), indicating that carvacrol is able to inhibit the release of inflammatory cytokines and suppress the oxidative stress. In the comparing the tissue oxidative stress parameters between the I/R injury groups, the TAS was significantly higher $(\mathrm{p}<0.001)$ and the TOS level was significantly lower $(\mathrm{p}<0.001)$ in the I/R-carvacrol treated group.

Table I

Tissue oxidative stress parameters of all groups

\begin{tabular}{|l|c|c|c|}
\hline \multicolumn{1}{|c|}{ Parameters } & Group 1 (Sham-control) & Group 2 (I/R-untreated) & Group 3 (I/R-carvacrol treated) \\
\hline MDA (nmol/mg protein) & $3.4 \pm 0.4$ & $33.6 \pm 6.2^{* \dagger}$ & $11.8 \pm 1.29$ \\
\hline SOD (mU/ug protein) & $9.2 \pm 0.8$ & $2.4 \pm 0.4^{* \dagger}$ & $20.4 \pm 2.2 \uparrow$ \\
\hline MPO (ng/ug protein) & $16.4 \pm 3.4$ & $157.8 \pm 7.6^{* \dagger}$ & $62.6 \pm 6.2 \uparrow$ \\
\hline TOS (nmol/mg protein) & $4.1 \pm 0.1$ & $8.8 \pm 0.8^{*} \dagger$ & $3.4 \pm 0.4$ \\
\hline TAS (mmol/mg protein) & $4.3 \pm 0.2$ & $1.8 \pm 0.2^{*} \dagger$ & $9.8 \pm 1.4 \uparrow$ \\
\hline
\end{tabular}

Malondialdehyde (MDA), myeloperoxidase (MPO) and total oxidant status (TOS) were significantly increased in intestinal tissues subjected to ischemia reperfusion injury but decreased by carvacrol treatment. The levels of superoxide dismutase (SOD) and total antioxidant status (TAS) in the intestinal tissue exposed to ischemia reperfusion (I/R) were increased by carvacrol treatment. * $\mathrm{p}<0.05$ (Group $2 v s .1$ ); $\dagger \mathrm{p}<0.05$ (Group $2 v s .3$ ), $\uparrow \mathrm{p}<0.05$ (Group $3 v s .1$ )

Table II

Histopathological parameters of all groups

\begin{tabular}{|l|c|c|c|}
\hline \multicolumn{1}{|c|}{ Parameters } & Group 1 (Sham-control) & Group 2 (I/R-untreated) & Group 3 (I/R-carvacrol treated) \\
\hline Chiu score & $0.4 \pm 0.2$ & $3.2 \pm 0.3^{* \dagger}$ & $1.2 \pm 0.1$ \\
\hline iNOS expression & $0.8 \pm 0.2$ & $2.5 \pm 0.2^{* \dagger}$ & $1.4 \pm 0.2$ \\
\hline eNOS expression & $1.4 \pm 0.2$ & $1 \pm 0.3$ & $2.4 \pm 0.2 ¥$ \\
\hline
\end{tabular}

The levels of intestinal tissue Chiu scores, inducible nitric oxide synthase (iNOS) and endothelial nitric oxide synthase (eNOS) from shamcontrol, I/R-untreated and I/R-carvacrol treated groups. Intestinal mucosal injury scores were decreased by carvacrol treatment in the intestinal tissues exposed to ischemia/reperfusion (I/R). In the I/R-carvacrol-treated group, the iNOS level was significantly lower and eNOS was significantly higher. * $\mathrm{p}<0.05$ (Group 2 vs. 1); $\dagger \mathrm{p}<0.05$ (Group 2 vs. 3), ¥p $<0.05$ (Group $3 v s .2$ ). 
In the I/R-untreated group, the intestinal mucosal injury score was significantly higher compared with that in the sham-control group $(\mathrm{p}<0.001)$. However, the quantitative analysis showed a significantly decreased mucosal injury score in the I/R-carvacrol treated group compared with that in the I/R-untreated group $(\mathrm{p}<$ 0.001 ), which showed that carvacrol treatment might play a protective effect in intestinal $\mathrm{I} / \mathrm{R}$ injury (Table II). In H\&E-stained intestine sections, normative histological changes were found in the sham-control group. In this group, intestinal epithelial villi aligned
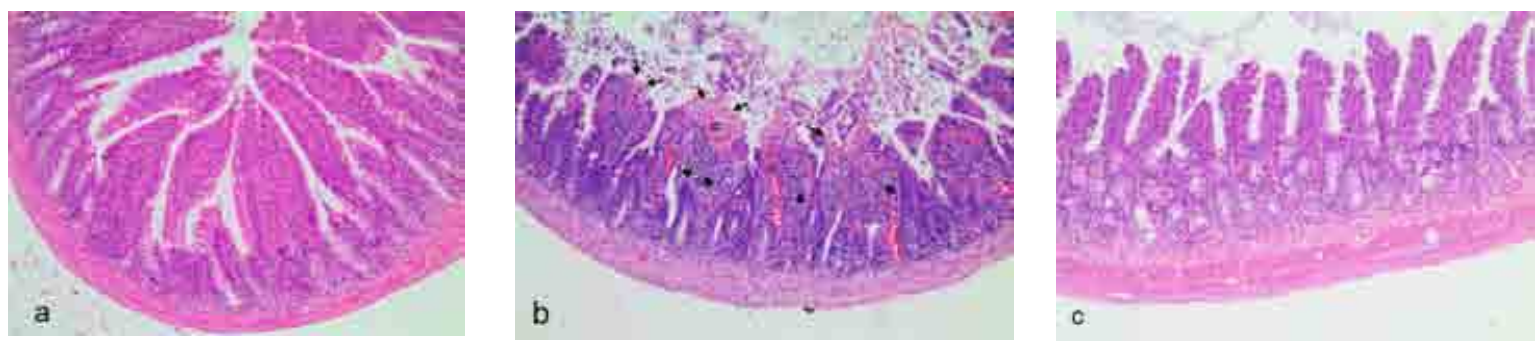

Figure 1.

Histopathological appearance of rat intestinal mucosa in all groups (haematoxylin and eosin staining, $\times 100$ ). a)

Sham-control rats demonstrated a normal histologic architecture. b) Rats subjected to intestinal ischemia reperfusion (I/R) injury: marked extended subepithelial space and epithelial lifting along the villis sides, denuded villi, and loss of villus tissue $(\rightarrow)$, congestion (c), and inflammatory cells ( $\rightarrow$ ). c) Rats subjected to intestinal I/R injury, pretreated with carvacrol: preserved the villi architecture
In the I/R-untreated group, iNOS expression was significantly elevated when compared with that in the sham-control and the I/R-carvacrol treated groups $(\mathrm{p}<0.001$ and $\mathrm{p}<0.002$ respectively), as shown in Table II and Figure 2a-c. In contrast, in the I/R- and formed a complete structure (Figure 1a). In accordance with Chiu's score, in the I/R-untreated group, the intestinal morphology was severely damaged and the intestine villus epithelial was broken, which exhibited interstitial hyperaemia, congestion and inflammatory cell infiltration (Figure $1 \mathrm{~b}$ ). In the I/Rcarvacrol treated group rats, most of the intestinal villi were normal, while a few inflammatory cells were infiltrated and a discrete congestion was observed at the capillary level (Figure 1c).

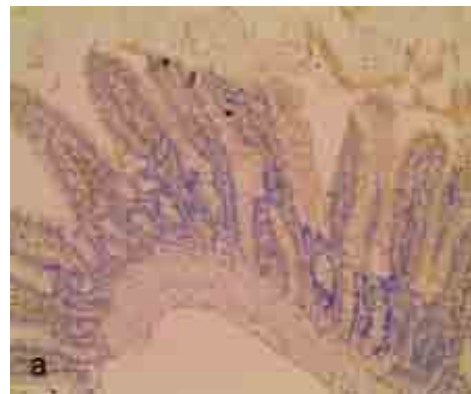

Examination of inducible nitric oxide synthase (iNO magnification, $x$ 100). (a) iNOS staining showed that there was mild change in control rats. (b) Significant increase in the number of iNOS-positive epithelial cells were observed in ischemia reperfusion group. (c) Expression of iNOS decreased in the carvacrol treatment group
The present research is the first study to evaluate and demonstrate the effects of carvacrol on reducing the negative consequences of $\mathrm{I} / \mathrm{R}$ injury in a rat model of intestinal I/R. The results of the present study showed that carvacrol treatment inhibited nitrosative and oxidative stress by reducing lipid peroxidation (MDA) levels, reducing iNOS expression, and by increasing antioxidants such as the SOD enzyme. In addition, carvacrol treatment reduced the $\mathrm{I} / \mathrm{R}$-induced increase in MPO carvacrol treated group, the mean value of eNOS expression in intestinal mucosal cells was significantly increased when compared with that I/R-untreated groups $(\mathrm{p}<0.007)$, as shown in Table II and Figure 3a-c.

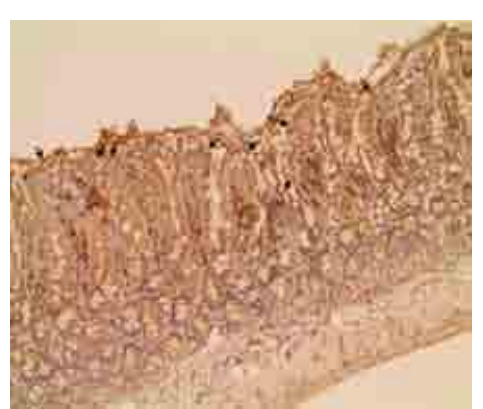

Figure 2.

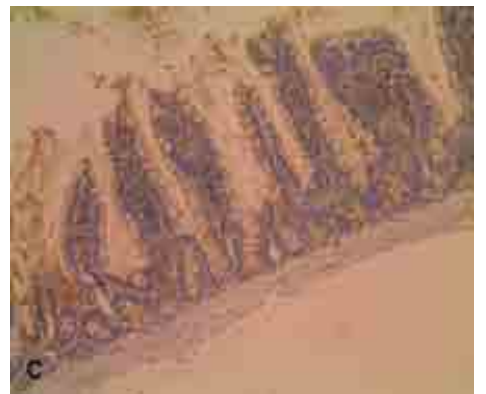

levels in ischemic intestinal tissues. These responses may be related to anti-inflammatory, cytoprotective factors and/or antioxidants.

Intestinal $\mathrm{I} / \mathrm{R}$ injury is an emergency medical condition with a high mortality rate. Ischemia, the interruption of blood supply, may cause damage to vital tissues. Although re-perfusion of tissues is important, it causes pathophysiological responses that lead to serious cell and tissue damage [17]. Several mediators have been 
included in intestinal I/R injury, such as the deposition of ROS, neutrophil infiltration, proinflammatory cytokines, chemokines, and apoptosis [18, 19]. Additionally, $\mathrm{I} / \mathrm{R}$ causes damage of the intestinal mucosal barrier and, then, bacterial translocation from the gut into the
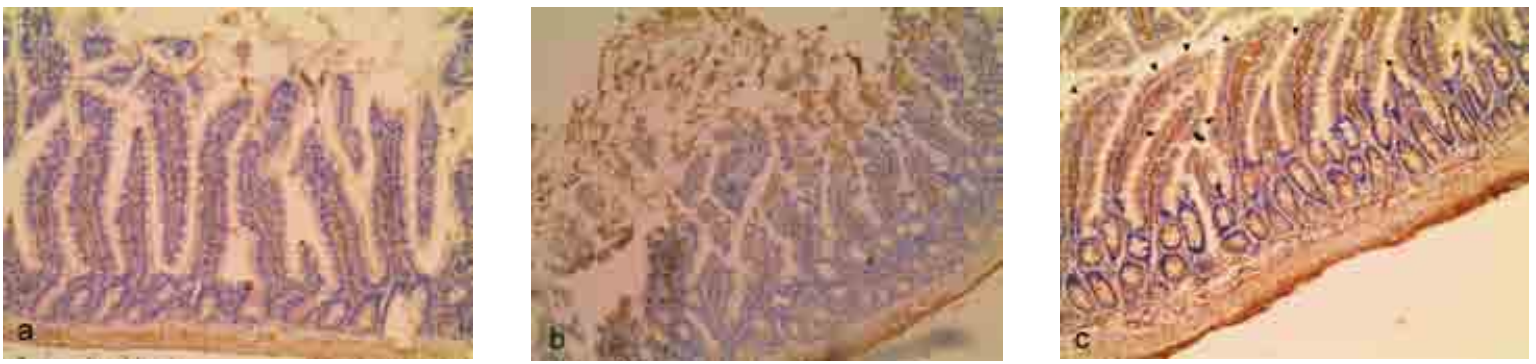

Figure 3.

Examination of endothelial nitric oxide synthase (eNOS) expression in intestinal tissues in all groups (original magnification, x100). (a) eNOS expression was found mean in the sham-control group. (b) eNOS expression in

$\mathrm{I} / \mathrm{R}$ - untreated group were decreased. (c) eNOS expression in the carvacrol-treated group was significantly higher in the epithelial cells

It is well known that ROS play important roles in the pathogenesis of $\mathrm{I} / \mathrm{R}$ injury, as they involve direct cellular injury, initiate a cascade of mediators, apoptosis, acute inflammatory changes, and necrosis [21, 22]. SOD is an important antioxidant in maintaining of the oxidative balance [23]. In addition, MDA, which is the product of free radical lipid peroxidation, is used in many studies as a standard to assess the level of $I / R$ injury [22, 24]. Carvacrol is a natural agent extracted from many plants of the Lamiaceae family, such as plants in the genera Origanum and Thymus [10, 25 ]. In a number of studies, its multiple effects and therapeutic potential were well-presented in several areas and on various diseases, as mentioned below. Many studies demonstrated that carvacrol has antiinflammatory [26], antimicrobial [27], antinociceptive, antithrombotic [28], antispasmodic [29], vasorelaxant [30], and antioxidant properties [31]. In a more recent study Li et al., in a mice model of focal cerebral I/R injury, showed that carvacrol inhibited the levels of inflammatory cytokines and MPO activity, as well as the expression of iNOS [32]. It also increased SOD activity and decreased MDA levels in ischemic cortical tissues. In another work, Canbek et al. demonstrated that carvacrol improved the biochemical changes in the liver caused by $I / R$, and there was no hepatotoxicity displayed at the chosen dose of carvacrol [33]. In the current study, lipid peroxidation was increased in the intestinal tissues of the rats after exposure to $\mathrm{I} / \mathrm{R}$, as demonstrated by elevated MDA production. However, carvacrol treatment markedly decreased MDA production and increased the activities of antioxidant enzymes, including SOD, following intestinal $\mathrm{I} / \mathrm{R}$ in rats. SOD is an enzyme that alternately catalyses the dismutation (or partitioning) of the superoxide $(\mathrm{O}-)$ radical into either typical molecular oxygen $(\mathrm{O})$ or hydrogen peroxide $(\mathrm{H} \mathrm{O})$. SOD is an important anti-oxidant defence mechanism for cells exposed to oxygen [34]. Additionally, the TOS level was significantly lower in the I/R-carvacrol treated group when compared to the I/R-untreated group. The decrease in the TOS level resulted from the carvacrol-induced increase in the antioxidant capacity of the tissue. In addition, histopathological analysis revealed that the intestinal tissue injury score markedly decreased in the I/R-carvacrol treated group compared to the I/R-untreated group.

$\mathrm{NO}$ is revealed from L-arginine by three types of nitric oxide synthase (NOS) enzymes, known as endothelial NOS (eNOS), neuronal NOS, and inducible NOS (iNOS) [35]. Among these isoforms, the expression of iNOS usually increases during the pathological processes and in response to proinflammatory cytokines. iNOS induces the production of large quantities of NO, thus, leading to the reperfusion induced intestinal injury [36]. Naito et al. demonstrated that inflammation induced by mesenteric reperfusion in rats resulted in oxidative and nitrosative stress, by the increased expression of iNOS and by an excess expression of lipidic peroxides [37]. Wu et al. suggested that iNOS is related to increased apoptosis in the small intestine mucosa of rats after I/R [38]. In this study, intestinal $\mathrm{I} / \mathrm{R}$ caused a significant increase in iNOS tissue expression compared with the sham-control group. Conversely, iNOS tissue expression levels were decreased in the I/R-carvacrol group. Additionally, in the I/R-carvacrol group, eNOS tissue expression levels were significantly increased.

The current study has some limitations. Firstly, carvacrol was administered before SMA occlusion which does not exactly match the clinical situation. Secondly, apoptosis was not examined directly and, we did not access more inflammatory cytokines and oxidative proteins that may have potential functions in it. 
However, we believe that our findings may provide useful clues for future research.

\section{Conclusions}

In the present study, we revealed that administration of carvacrol increased the levels of SOD, TAS and eNOS but decreased the levels of MDA, MPO, TOS and $\mathrm{iNOS}$ in the $\mathrm{I} / \mathrm{R}$ rats. This indicates that carvacrol may alleviate $\mathrm{I} / \mathrm{R}$ injury by an increase of the antioxidative activity and suppression of inflammatory cell infiltration as well as preservation of intestinal mucosal damage. These results suggested that carvacrol may be a novel therapeutic agent for the protection of intestinal mucosal tissue against I/R injury.

\section{References}

1. Acosta S, Epidemiology of mesenteric vascular disease: clinical implications. Semin Vasc Surg., 2010; 23(1): 4-8.

2. Taha MO, de Oliveira JV, Dias Borges M, de Lucca Melo F, Gualtieri FG, E Silva Aidar AL, Pacheco RL, de Melo Alexandre E Silva T, Klajner RK, Iuamoto LR, Munhoz Torres L, Morais Mendes de Paula BJ, de Campos K, Oliveira-Junior IS, Fagundes DJ, LArginine modulates intestinal inflammation in rats submitted to mesenteric ischemia-reperfusion injury. Transplant Proc., 2016; 48(2): 512-515.

3. Shu X, Zhang J, Wang Q, Xu Z, Yu T, Glutamine decreases intestinal mucosal injury in a rat model of intestinal ischemia-reperfusion by downregulating HMGB1 and inflammatory cytokine expression. Exp Ther Med., 2016; 12(3): 1367-1372.

4. Akcılar R, Akcılar A, Koçak C, Koçak FE, Bayat Z, Şimşek H, Şahin S, Savran B, Effects of Ukrain on intestinal apoptosis caused by ischemia-reperfusion injury in rats. Int $J$ Clin Exp Med., 2015; 8(12): 22158-22166.

5. Tassopoulos A, Chalkias A, Papalois A, Iacovidou N, Xanthos T, The effect of antioxidant supplementation on bacterial translocation after intestinal ischemia and reperfusion. Redox Rep., 2017; 22(1): 1-9.

6. de Groot H, Rauen U, Ischemia-reperfusion injury: processes in pathogenetic networks: a review. Transplant Proc., 2007; 39(2): 481-484.

7. Wang G, Yao J, Li Z, Zu G, Feng D, Shan W, Li Y, Hu Y, Zhao Y, Tian X, miR-34a-5p Inhibition Alleviates Intestinal Ischemia/Reperfusion-Induced Reactive Oxygen Species Accumulation and Apoptosis via Activation of SIRT1 Signaling. Antioxid Redox Signal., 2016; 24(17): 961-973.

8. Cerqueira NF, Hussni CA, Yoshida WB, Pathophysiology of mesenteric ischemia/reperfusion: a review. Acta Cir Bras., 2005; 20(4): 336-343.

9. Zhang ZX, Shek K, Wang S, Huang X, Lau A, Yin Z, Sun H, Liu W, Garcia B, Rittling S, Jevnikar AM, Osteopontin expressed in tubular epithelial cells regulates NK cell-mediated kidney ischemia reperfusion injury. J Immunol., 2010; 185(2): 967-973.

10. Ultee A, Kets EP, Smid EJ, Mechanisms of action of carvacrol on the food-borne pathogen Bacillus cereus. Appl Environ Microbiol., 1999; 65(10): 4606-4610.

11. Samarghandian S, Farkhondeh T, Samini F, Borji A, Protective effects of carvacrol against oxidative stress Induced by Chronic Stress in Rat's Brain, Liver, and Kidney. Biochem Res Int., 2016; 2016: 2645237: 1-7.

12. Pushpavalli G, Kalaiarasi P, Veeramani C, Pugalendi $\mathrm{KV}$, Effect of chrysin on hepatoprotective and antioxidant status in D-galactosamine-induced hepatitis in rats. Eur J Pharmacol., 2010; 631(1-3): 36-41.

13. Kara M, Uslu S, Demirci F, Temel HE, Baydemir C, Supplemental carvacrol can reduce the severity of inflammation by influencing the production of mediators of inflammation. Inflammation, 2015; 38(3): 1020-1027.

14. Arumugam TV, Shiels IA, Margolin SB, Taylor SM, Brown L, Pirfenidone attenuates ischaemia-reperfusion injury in the rat small intestine. Clin Exp Pharmacol Physiol., 2002; 29(11): 996-1000.

15. Chiu CJ, McArdle AH, Brown R, Scott HJ, Gurd FN, Intestinal mucosal lesion in low-flow states. I. A morphological, hemodynamic, and metabolic reappraisal. Arch Surg., 1970; 101(4): 478-483.

16. Fu Y, Lin Q, Gong T, Sun X, Zhang ZR, Renal-targeting triptolide-glucosamine conjugate exhibits lower toxicity and superior efficacy in attenuation of ischemia/reperfusion renal injury in rats. Acta Pharmacol Sin., 2016; 37(11): 1467-1480.

17. Di Paola R, Impellizzeri D, Torre A, Mazzon E, Cappellani A, Faggio C, Esposito E, Trischitta F, Cuzzocrea S, Effects of palmitoylethanolamide on intestinal injury and inflammation caused by ischemiareperfusion in mice. $J$ Leukoc Biol., 2012; 91(6): 911-920.

18. Paterniti I, Galuppo M, Mazzon E, Impellizzeri D, Esposito E, Bramanti P, Cuzzocrea S, Protective effects of apocynin, an inhibitor of NADPH oxidase activity, in splanchnic artery occlusion and reperfusion. $J$ Leukoc Biol., 2010; 88(5): 993-1003.

19. Kang KJ, Mechanism of hepatic ischemia/reperfusion injury and protection against reperfusion injury. Transplant Proc., 2002; 34(7): 2659-2661.

20. Zhu Q, He G, Wang J, Wang Y, Chen W, Pretreatment with the ALDH2 agonist Alda-1 reduces intestinal injury induced by ischaemia and reperfusion in mice. Clin Sci (Lond.), 2017; 131(11): 1123-1136.

21. Datta G, Fuller BJ, Davidson BR, Molecular mechanisms of liver ischemia reperfusion injury: insights from transgenic knockout models. World J Gastroenterol., 2013; 19(11): 1683-1698.

22. Suo L, Kang K, Wang X, Cao Y, Zhao H, Sun X, Tong $\mathrm{L}$, Carvacrol alleviates ischemia reperfusion injury by regulating the PI3K-Akt pathway in rats. PLoS One, 2014; 9(8): e104043: 1-10.

23. Lehmann TG, Wheeler MD, Froh M, Schwabe RF, Bunzendahl H, Samulski RJ, Lemasters JJ, Brenner DA, Thurman RG, Effects of three superoxide dismutase genes delivered with an adenovirus on graft function after transplantation of fatty livers in the rat. Transplantation, 2003; 76(1): 28-37.

24. Cámara-Lemarroy CR, Guzmán-de la Garza FJ, AlarcónGalván G, Cordero-Pérez P, Fernández-Garza NE, The effects of NMDA receptor antagonists over intestinal 
ischemia/reperfusion injury in rats. Eur J Pharmacol., 2009; 621(1-3): 78-85.

25. Oliveira IS, da Silva FV, Viana AF, dos Santos MR, Quintans-Júnior LJ, Martins Mdo C, Nunes PH, Oliveira Fde A, Oliveira Rde C, Gastroprotective activity of carvacrol on experimentally induced gastric lesions in rodents. Naunyn Schmiedebergs Arch Pharmacol., 2012; 385(9): 899-908.

26. Landa P, Kokoska L, Pribylova M, Vanek T, Marsik $\mathrm{P}$, In vitro anti-inflammatory activity of carvacrol: Inhibitory effect on COX-2 catalyzed prostaglandin $\mathrm{E}(2)$ biosynthesis. Arch Pharm Res., 2009; 32(1): 75-78.

27. Ben Arfa A, Combes S, Preziosi-Belloy L, Gontard N, Chalier P, Antimicrobial activity of carvacrol related to its chemical structure. Lett Appl Microbiol., 2006; 43(2): 149-154.

28. Enomoto S, Asano R, Iwahori Y, Narui T, Okada Y, Singab AN, Okuyama T, Hematological studies on black cumin oil from the seeds of Nigella sativa L.. Biol Pharm Bull., 2001; 24(3): 307-310.

29. Van den Broucke CO, Lemli JA, Antispasmodic activity of Origanum compactum. Part 2: Antagonistic effect of thymol and carvacrol. Planta Med., 1982; 45(3): 188-190.

30. Peixoto-Neves D, Silva-Alves KS, Gomes MD, Lima FC, Lahlou S, Magalhães PJ, Ceccatto VM, Coelhode-Souza AN, Leal-Cardoso JH, Vasorelaxant effects of the monoterpenic phenol isomers, carvacrol and thymol, on rat isolated aorta. Fundam Clin Pharmacol., 2010; 24(3): 341-350.

31. Guimarães AG, Oliveira GF, Melo MS, Cavalcanti SC, Antoniolli AR, Bonjardim LR, Silva FA, Santos JP, Rocha RF, Moreira JC, Araújo AA, Gelain DP, Quintans-Júnior LJ, Bioassay-guided evaluation of antioxidant and antinociceptive activities of carvacrol. Basic Clin Pharmacol Toxicol., 2010; 107(6): 949-957.
32. Li Z, Hua C, Pan X, Fu X, Wu W, Carvacrol exerts neuroprotective effects via suppression of the inflammatory response in middle cerebral artery occlusion rats. Inflammation, 2016; 39(4): 1566-1572.

33. Canbek M, Uyanoglu M, Bayramoglu G, Senturk H, Erkasap N, Koken T, Uslu S, Demirustu C, Aral E, Husnu Can Baser K, Effects of carvacrol on defects of ischemia-reperfusion in the rat liver. Phytomedicine, 2008; 15(6-7): 447-452.

34. McCord JM, Fridovich I, Superoxide dismutase: the first twenty years (1968-1988). Free Radic Biol Med., 1988; 5(5-6): 363-369.

35. Diaz-Ruiz A, Vergara P, Perez-Severiano F, Segovia J, Guizar-Sahagún G, Ibarra A, Ríos C, CyclosporinA inhibits constitutive nitric oxide synthase activity and neuronal and endothelial nitric oxide synthase expressions after spinal cord injury in rats. Neurochem Res., 2005; 30(2): 245-251.

36. Ozacmak HS, Ozacmak VH, Barut F, Araslı M, Ucan $\mathrm{BH}$, Pretreatment with mineralocorticoid receptor blocker reduces intestinal injury induced by ischemia and reperfusion: involvement of inhibition of inflammatory response, oxidative stress, nuclear factor $\kappa \mathrm{B}$, and inducible nitric oxide synthase. J Surg Res., 2014; 191(2): 350-361.

37. Naito $Y$, Takagi $T$, Uchiyama $K$, Handa $O$, Tomatsuri N, Imamoto E, Kokura S, Ichikawa H, Yoshida N, Yoshikawa T, Suppression of intestinal ischemiareperfusion injury by a specific peroxisome proliferatoractivated receptor-gamma ligand, pioglitazone, in rats. Redox Rep., 2002; 7(5): 294-299.

38. Wu B, Iwakiri R, Tsunada S, Utsumi H, Kojima M, Fujise T, Ootani A, Fujimoto K, iNOS enhances rat intestinal apoptosis after ischemia-reperfusion. Free Radic Biol Med., 2002; 33(5): 649-658. 